\title{
Richness of zoonotic viruses in bats and bat-human interaction pose the indication of current and future pandemics
}

\author{
Shahneaz Khan ${ }^{1}$, Mohammed Imtiaz ${ }^{2}$, and Mohammad Mahmudul Hassan ${ }^{2}$ \\ ${ }^{1}$ Chittagong Veterinary and Animal Sciences University \\ ${ }^{2}$ Chittagong Veterinary and Animal Science University
}

May 11, 2020

\begin{abstract}
Bats are a natural reservoir of many pathogenic and non-pathogenic viruses with the chance of spill over via the intermediate host and/ directly to human. The number of zoonotic and deadly viruses especially RNA viruses originated from bats is remarkable. The recent outbreak of COVID 19 or SARS-Cov-2 is the novel or new version of continuation of virus spill over the last few decades. The previous outbreaks as such MERS, SARS predominantly infect human respiratory systems with limited human to human transmission capability. The human interface with wildlife along with deforestation, urbanization, overgrown population, bush meat hunting, wildlife trade significantly increase the reassortment of bat originated virus with other intermediate host to jump in to human species. In this review, we discussed the history of bat borne pathogen and the triggering factors that impose their spill over to human for generating current and future pandemics.
\end{abstract}

\section{Hosted file}

Main text.doc available at https://authorea.com/users/320782/articles/450183-richness-ofzoonotic-viruses-in-bats-and-bat-human-interaction-pose-the-indication-of-current-andfuture-pandemics

\section{Hosted file}

Table 1.docx available at https://authorea.com/users/320782/articles/450183-richness-ofzoonotic-viruses-in-bats-and-bat-human-interaction-pose-the-indication-of-current-andfuture-pandemics 


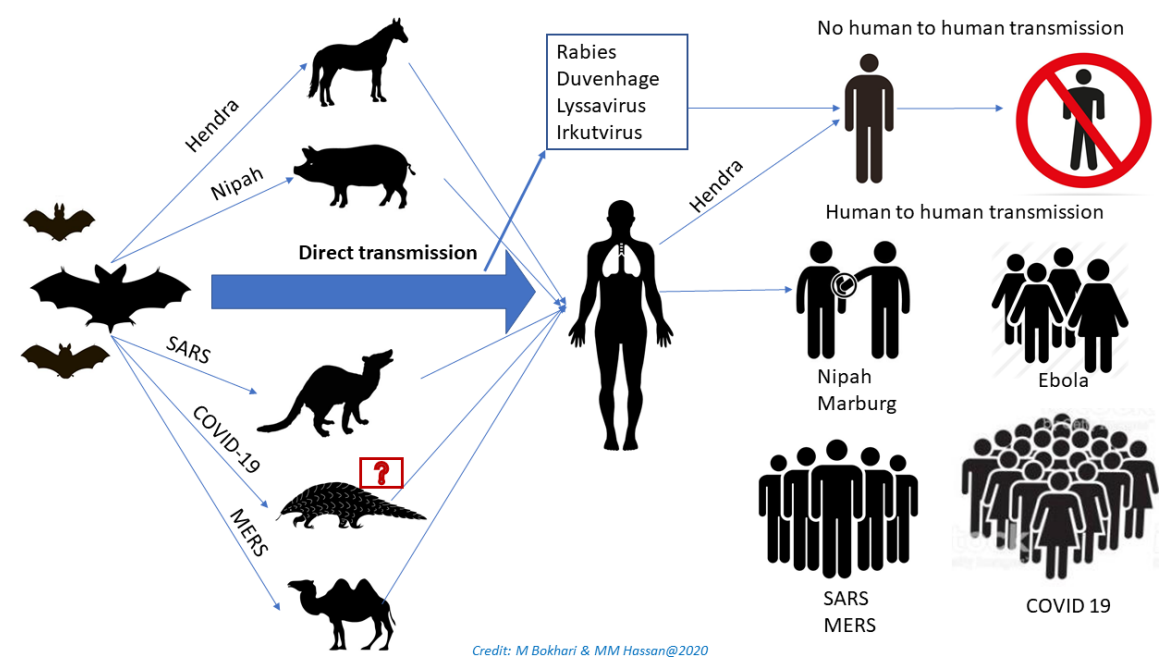

